\title{
Integrated toxicity evaluation of a pulp deposit using organisms of different trophic levels
}

\author{
Cornelia Kienle • Miriam Langer-Jaesrich • \\ Daniela Baumberger • Doris Hohmann • Sergio Santiago • \\ Heinz-R. Köhler • Daniel Zürrer • Almut Gerhardt
}

Received: 15 October 2012 / Accepted: 30 May 2013 / Published online: 1 August 2013

(C) Springer-Verlag Berlin Heidelberg 2013

\begin{abstract}
Purpose In order to assess possible adverse effects originating from pulp deposits in a Swiss lake, a sediment quality triad approach was applied with chemical, ecotoxicological and ecological assessment methods.

Materials and methods To obtain an integrative picture of the potential ecotoxicological effects on organisms of different trophic levels, four test procedures were applied. The acute effects of pulp deposit pore water on a decomposer, the amphipod Gammarus fossarum, were monitored. Chronic toxicity of the pore water was evaluated on primary producers via a growth inhibition test with unicellular green algae (Pseudokirchneriella subcapitata) and on secondary consumers in a reproduction test with the water flea Ceriodaphnia dubia. To evaluate the effects of the pulp deposit on sediment inhabitants, a whole-life-cycle
\end{abstract}

Responsible editor: Henner Hollert

Electronic supplementary material The online version of this article (doi:10.1007/s11368-013-0733-z) contains supplementary material, which is available to authorized users.

C. Kienle $(\bowtie) \cdot$ D. Baumberger $\cdot$ A. Gerhardt

Swiss Centre for Applied Ecotoxicology Eawag/EPFL,

Überlandstrasse 133, 8600 Dübendorf, Switzerland

e-mail: cornelia.kienle@oekotoxzentrum.ch

M. Langer-Jaesrich • H.-R. Köhler

Animal Physiological Ecology, University of Tübingen,

Konrad-Adenauer-Str. 20, 72072 Tübingen, Germany

D. Hohmann

Eawag Aquatic Research, Department of Aquatic Ecology,

Seestrasse 79, 6047 Kastanienbaum, Switzerland

S. Santiago

Soluval Santiago, Rue Edouard Dubied 2,

2108 Couvet, Switzerland test with the non-biting midge Chironomus riparius was undertaken. Chemical assessment included dissolved organic carbon, extractable organic halogenic compounds, polychlorinated biphenyls (PCBs), polycyclic aromatic hydrocarbons (PAHs) and heavy metals. The composition of the macrozoobenthos community was analysed in order to assess the ecological effects.

Results and discussion G. fossarum displayed increased locomotor activity at $12.5 \%$ but not at $25 \%$ sample concentration during a short-time exposure of $20 \mathrm{~h}$. Chronic effects compromised the reproduction and growth of C. dubia (lowest observed effect concentration, $12.5 \%$ sample concentration) with zero population growth in $100 \%$ pulp deposit pore water. In $100 \%$ pulp deposit, C. riparius exhibited increased mortality at 10 and 17 days after oviposition. Pulp deposits of 50\%

D. Zürrer

CSD Engineers and Geologists Ltd, Hardturmstrasse 135, 8005 Zürich, Switzerland

Present Address:

D. Zürrer

Baudirektion Kanton Zürich, Walchetor 8090 Zurich, Switzerland

Present Address:

A. Gerhardt

LimCo International, Technologiezentrum Konstanz, Blarerstraße 5678462 Konstanz, Germany 
and $100 \%$ concentration caused a significantly lower emergence compared with the reference treatments (lake sediment and quartz sand). Additionally, the locomotor activity of chironomids decreased significantly in $25-100 \%$ pulp deposit. No chronic effects of pulp deposit pore water on algae photosynthesis and growth could be detected. The bioassay results were in accordance with an elevated content of PAHs, PCBs and metals in the pulp deposit. Significantly more organisms known to be tolerant to organic pollution were present within the macrozoobenthos community. Conclusions In general, for sediment inhabitants such as chironomids, the pulp deposit has to be classified toxic. In the present test setup, the toxicity of the pulp deposit was reflected better by the chronic test systems applied than by the acute ones. The applied testing framework could be a suitable tool to assess the risk of contaminated sites, and this information will help decide whether risk mitigation measures should be taken. In addition, with a similar approach, the success of any mitigation measures taken can be assessed.

Keywords Integrated assessment · Sediment quality assessment $\cdot$ Sediment triad $\cdot$ Trophic levels

\section{Introduction}

Sediments represent a complex environmental matrix and can be a sink for various pollutants. The crucial question is how the possible risks that a sediment may pose to the environment can be assessed. Up to now, several approaches have been applied. In order to evaluate whether sediment is contaminated and toxic and whether the organisms in the sediment are impacted, a three-component approach was proposed (Ahlf 1995) using a sediment quality triad approach (Chapman 1986). This approach concerns the components: (1) sediment chemistry (exposure assessment); (2) sediment toxicity and (3) an assessment of the benthos community, e.g. structure of biocenosis (effect assessment) (Chapman et al. 1992). Such an integrative approach has already been applied in various studies, e.g. in the UK, the Czech Republic and Germany (for a review, see Hollert et al. 2009). In recent years, an update of the "classical" sediment quality triad has evolved, adding several lines of evidence in order to obtain a more complete picture of the problems being assessed (Chapman and Hollert 2006). Hecker and Hollert (2009) suggested an extension to the sediment quality triad by including effect-directed analysis, in order to be able to identify the pollutants responsible for the effects. Gerbersdorf et al. (2011) strove for a "triad plus x" approach, with a combination of advanced methods of ecotoxicology, environmental microbiology and engineering science, and Wolfram et al. (2012) developed a weight-of-evidence approach to assess the influence of chemical pollution on benthic invertebrates in streams. From the results of such triad studies, effect-based sediment quality guidelines can be derived (e.g. de Deckere et al. 2011), enabling chemical pollution to be set in context with probable ecotoxicological effects.

However, despite the many publications on sediment quality assessment, the risks of some specific sediment deposits, such as those originating from pulp and paper production, are presently not well assessed. In earlier studies, mostly bioassays (e.g. Bertoletti et al. 1988; McKinney and Wade 1996; Bailey and Young 1997) were performed, but an approach for the integrative assessment of such effluents or deposits is lacking. The previous studies showed that pulp and paper mill effluents and deposits can exhibit harsh effects on organisms. Costan et al. (1993) even identified them as the most toxic type of wastewater amongst several different types of effluent tested (e.g. pulp and paper, petroleum refining, inorganic/organic chemical production, mining, metallurgy, metal plating and textile production). Bailey and Young (1997) suggested a multi-species approach for the toxicity assessment of such effluents in order to achieve a robust response, as no correlation between the different endpoints investigated for various species (algae: Pseudokirchneriella subcapitata; water flea: Ceriodaphnia dubia and fish: Oncorhynchus mykiss) was detected.

In order to improve upon the sparse information on this important type of pollution, the above-described sediment quality triad approach was applied to evaluate a pulp deposit. This deposit, located in a Swiss lake, was caused by a former paper mill. Despite the pre-treatment of the sewage water, a significant amount of paper fibres accumulated over many decades. To date, the pulp deposit covers the lake sediments with an area of several $1,000 \mathrm{~m}^{2}$. The pulp deposit layer varies in thickness between a few centimetres to a maximum of $1.5 \mathrm{~m}$, with a water depth of 7 to $28 \mathrm{~m}$.

From the large suite of chemical and biological methods available (for a review, see Hollert et al. 2009), four bioassays were selected with organisms of different trophic levels in order to cover the potential effects; from primary producers to secondary consumers to detritus feeders including acute and chronic endpoints. This bioassay suite for effects assessment was supplemented with an exposure assessment by chemical analyses. In order to obtain an overview of the relevant pollutants to be expected in the deposit (e.g. Murray 1992; Kersten et al. 2006), heavy metal screening and analyses concerning polychlorinated biphenyls (PCBs), extractable organically bound halogens (EOXs), dissolved organic carbon (DOC) and polyaromatic hydrocarbons (PAHs) were conducted. For an effects assessment at the community level (Chapman and Hollert 2006), the macrozoobenthos community was also assessed.

The aim of this study was to assess the potential environmental risk posed by the pulp deposit on organisms of different trophic levels, as well as the macrozoobenthos 
community. Furthermore, we wanted to address whether the toxicity could be determined by acute tests in comparison to chronic ones. Another aim was to evaluate whether the toxicity of the deposit could be reflected by a 1-week, and thereby less costly, reproduction test with a pelagic organism (C. dubia), compared with a 4-week test using sedimentinhabiting organisms (e.g. Chironomus riparius). With the applied testing framework, we want to offer a suitable suggestion for an integrative toxicity assessment of sediment deposits.

\section{Materials and methods}

\subsection{Sampling procedure and sample preparation}

The sediment and water samples were taken in a Swiss lake on 25.11.2008; the lake cannot be named in order to protect the identity of the pulp and paper mill. Sediments were taken as grab samples from the deposit site in approximately $5 \mathrm{~m}$ depth of water. For the bioassays and the chemical analysis, $10 \mathrm{~kg}$ of pulp deposit and $10 \mathrm{~kg}$ of sediment from an unpolluted site in the vicinity of the deposit (lake reference sediment) were taken. Additionally, 101 of lake water was sampled. In order to assess the composition of the macrozoobenthos community, additional sediment samples were collected (eight pulp deposit and eight lake sediment samples weighing between 5.5 and $6.3 \mathrm{~kg}$ each) with a van Veen grab sampler.

The samples were kept overnight at $+4^{\circ} \mathrm{C}$. For chemical analysis, the samples were centrifuged the following day and dried at $105^{\circ} \mathrm{C}$. For homogenisation purposes, the dried samples were treated with a cutting mill prior to analysis.

For the whole-life-cycle test with $C$. riparius, which was performed with native/untreated sediment, 11 of the sediment was first frozen. The remaining sediment was centrifuged with an ultracentrifuge $\left(30 \mathrm{~min}\right.$ at $+4^{\circ} \mathrm{C}$ and $\left.3,000 \times \mathrm{g}\right)$, and the pore water as the supernatant was filled in glass bottles (Schott, Mainz, Germany) and stored at $4{ }^{\circ} \mathrm{C}$ in the dark prior to the experiment. With this pore water, assays with $P$. subcapitata, Gammarus fossarum and C. dubia were prepared.

In the assay with $G$. fossarum, the amphipods were exposed to the untreated pore water. For the test with $C$. dubia, the fine sediment particles remaining in the pore water were allowed to settle to the base of the glass bottle in order to avoid interference in the test of suspended particulate matter. Sedimentation was preferred over filtering for this assay, in order to avoid a change in the constitution of the water. The water used in the algae assay was first filtered $(16 \mu \mathrm{m}$ Whatman paper filter) to remove the remaining pulp particles which could falsify cell density measurement.

For the assay with $C$. riparius, the pulp deposit and lake sediment were defrosted and mixed with the respective proportion of quartz sediment (Dehner, Germany, particle size $0.1-0.3 \mathrm{~mm}$, heated for $3 \mathrm{~h}$ at $500^{\circ} \mathrm{C}$ to remove organic matter) to obtain different dilutions of $100 \%, 50 \%, 25 \%$, $12.5 \%$ and $6.25 \%$ pulp deposit concentrations. A first measure of the mixed sediments was used immediately in the tests; others were frozen once again before use. Two different control treatments were analyzed: Pure quartz sand served as an internal control, whereas the lake sediment served as natural reference sediment and the effects compared with the effects with the pulp deposit.

\subsection{Chemical analysis}

In the homogenised sample of the pulp deposit as well as in the lake water and the pore water of the lake sediment and the pulp deposit, the following parameters were analysed. DOC was assessed in the liquid samples using a carbon hydrogen nitrogen elemental analyser (HEKAtech, Wegberg, Germany). The total amount of hydrocarbons $\mathrm{C}_{10}-\mathrm{C}_{40}$ was determined in the pulp deposit according to ISO 16703/DIN EN 14039 (International Organization for Standardization 2004; Deutsches Institut für Normung 2005), and EOX was assessed according to DIN 38414-17 (Deutsches Institut für Normung 1989).

Measurement of PCBs in solid materials was conducted according to US Environmental Protection Agency (USEPA) method 8082 (EPA 1996a) by gas chromatography equipped with an electron capture detector (GC-ECD), following clean-up-extraction using accelerated solvent extraction (ASE), and in water according to ISO 6468 (International Organization for Standardization 1996) by GC-ECD following liquid-liquid extraction.

The evaluation of the PAHs in solid materials was performed according to USEPA method 8270 (EPA 1996b) by ASE and gas chromatography/mass spectrometry.

Heavy metals were assessed via quantitative screening by $\mathrm{X}$-ray fluorescence analysis.

\subsection{Bioassays}

\subsubsection{Experimental structure of the study}

In the present study, effects on primary producers were assessed in a 24-h algae assay with single-celled green algae (P. subcapitata), which additionally serve as food for zooplankton organisms. This test presents a combination of the detection of photosynthesis inhibition, based on the inhibition of photosystem II by certain herbicides, and growth inhibition (Escher et al. 2008).

Effects on secondary consumers were assessed in a chronic bioassay with aquatic crustaceans, the water flea $C$. dubia. As an important part of the zooplankton in standing water bodies, they feed on algae and serve as a food base for fish and other 
aquatic organisms (e.g. Lynch 1978). C. dubia is a standard test organism for the ecotoxicological analysis of chemicals and wastewater (AFNOR 2000; EPA 2002), where chronic effects on its reproduction and growth are assessed. Effects on decomposers (shredders and exploiters of organic matter) were evaluated with amphipods, which are key organisms in freshwater ecosystems (both lakes and streams), important prey organisms for fish and widely distributed around Europe (Karaman and Pinkster 1977; Welton 1979). For one species of Gammarus (G. fossarum), the acute effects on locomotor and ventilatory activities were evaluated. G. fossarum was selected as one of the two indigenous Gammarus species. In recent years, an invasive species (Dikerogammarus villosus) also infested several Swiss lakes and rivers.

Due to their high ecological relevance, sediment-inhabiting organisms were also included, since they are directly exposed to the toxic substances present there. The influence of lake sediment as a reference sediment and of pulp deposits in different dilutions on larvae of the non-biting midge $C$. riparius were evaluated in an extended whole-life-cycle assay (OECD 2004a, b) according to the survival rate, locomotor and ventilatory activity of two larval stages, as well as the emergence of the C. riparius being monitored (LangerJaesrich et al. 2010a).

\subsubsection{Combined algae assay}

This test was conducted as described by Escher et al. (2008), with an adjustment for environmental samples (two times concentrated algae medium). The filtered samples were mixed at 1:1 with the double-concentrated test medium. Diuron served as a positive control (initial concentration: $3 \times 10^{-7} \mathrm{M}$ in ethanol) and a pure algae test medium and ethanol (50 $\mu \mathrm{l} / \mathrm{well}, n=8$ wells/plate) as negative controls. After the complete ablation of the solvents, the substances were resuspended in $100 \mu \mathrm{l}$ algae medium. Environmental samples were added directly to the wells and subsequently diluted in a 1:2 dilution series. Finally, $100 \mu$ of algae suspension with an optical density $\mathrm{OD}_{685}$ of 0.1 was added to each well, resulting in a $25 \%$ sample concentration in the first well. Photosynthesis inhibition by means of effective quantum yield was measured using a Maxi-Imaging pulse amplitude modulation (IPAM) device (Walz, Effeltrich, Germany) - as described by Escher et al. (2008) and Schreiber et al. (2007)after 2 and $24 \mathrm{~h}$. The growth of algae was measured by means of absorbance at $685 \mathrm{~nm}$ in a microtitre plate photometer (Synergy 4, Biotek, Winooski, USA) at regular intervals (after $0,2.5,14.5$ and $24 \mathrm{~h}$ of exposure).

\subsubsection{Acute test with G. fossarum}

Adult G. fossarum (size approximately $5-8 \mathrm{~mm}$ ) were collected in the Bäntal near Tüfels Chilen (Nussberg,
Schlatt, Switzerland) and stored in the laboratory in a mixture of aerated tap water and stream water (50:50) for 1 week before the onset of the test. Partly decomposed alder leaves (Alnus glutinosa), from the unpolluted stream where the animals were collected, were supplied as food and refuge during the test.

Less than $24 \mathrm{~h}$ after sample collection, the test was carried out. Five individuals of G. fossarum were exposed in 600-ml glass beakers (Schott, Mainz, Germany) containing $200 \mathrm{ml}$ samples (either control water, lake water, lake sediment pore water or pulp deposit pore water). Exposure was performed at room temperature (approximately $18^{\circ} \mathrm{C}$ ). Control and lake water were tested undiluted, while four to five concentrations of the pulp deposit and reference sediment pore water were assessed in a geometric row with a dilution factor of 2, ranging from $25 \%$ to $3.13 \%$. For each treatment, two replicates with five individuals each were assessed in a static system. After 2 and $20 \mathrm{~h}$ exposure, the movement and ventilation activity of five amphipods per treatment (randomly selected animals from each of the two replicates) were measured with the Multispecies Freshwater Biomonitor ${ }^{\circledR}$ (MFB). The MFB is an online biomonitor for the continuous quantitative recording of organism behaviour, which is able to detect changes in a weak electric field caused by the movement of organisms in test chambers (Gerhardt et al. 1994, 1998). For behaviour measurements, individual amphipods were gently transferred to measuring chambers $(4 \times 2 \mathrm{~cm}$, covered by a $2.5 \mathrm{~mm}$ mesh $)$ with one amphipod per chamber and a $\sim 1 \mathrm{~cm}$ leaf fragment added as food and refuge. The measurement chambers were placed horizontally in a glass aquarium filled with tap water during measurement, and the movement activity of animals was recorded for 30-50 min in total (three to five measurement periods). After measurement, the gammarids were returned to the test beakers. Mortality was determined visually once per day after 2, 24 and $48 \mathrm{~h}$ exposure.

\subsubsection{Chronic reproduction test with C. dubia}

In this bioassay, chronic effects on the reproduction of the cladoceran $C$. dubia were assessed after 7 and 8 days (population growth inhibition test, according to ISO 20665 (International Organization for Standardization 2008) and AFNOR T90-376 (AFNOR 2000).

The test was carried out with the control-dilution medium corresponding to a moderately hard water prepared by mixing 25\% Evian mineral water, 25\% Elendt M4 medium and 50\% deionised water, supplemented with selenium and vitamin B12. Food was composed of a mixture with yeast, digested fish flake suspension $\left(\right.$ TetraMin $\left.^{\circledR}\right)$ and green algae $(P$. subcapitata and Chlorella sp.). This slightly modified version of the standards allowed the validity criteria to be met.

Test animals were obtained from a laboratory culture (Soluval Santiago, Couvet). Neonates (less than $24 \mathrm{~h}$ old 
and within $8 \mathrm{~h}$ of the same age at the start of the test) were exposed for up to 8 days to different solutions. The control and the lake reference samples were tested undiluted, while five to six concentrations of pulp deposit and reference sediment pore water were assessed in a geometric row with a dilution factor of 2 , ranging from $100 \%$ to $3.13 \%$ sample concentration. For each treatment, 11-14 replicates with one individual each were assessed in a static-renewal system. All tests were carried out at $25 \pm 1^{\circ} \mathrm{C}$ in an environmental chamber, with illumination ranging from 300 to 500 lux and a 16:8 $\mathrm{h}$ light-dark photoperiod. Every day, at the time of water renewal, the survival of the mothers and offspring in each vessel was counted. Average population growth was calculated/reported as the number of live offspring per treatment divided by the number of replicates. Data were normalised to the control (100\% growth).

Physico-chemical characteristics of the sample solutions $(\mathrm{pH}$, dissolved oxygen [milligrams per litre] and electric conductivity [microsiemens per centimetre]) were measured at the beginning and end of the test and at four time points during the course of the test.

\subsubsection{Extended whole-life-cycle test with C. riparius}

The extended whole-life-cycle test was performed as described by Langer-Jaesrich et al. (2010a). In brief, the experiments were conducted in an environmental chamber at $21.0 \pm 0.5^{\circ} \mathrm{C}$, with a light-dark cycle of $16: 8 \mathrm{~h}$ using artificial daylight. Each treatment was replicated four times; the treatment with natural reference sediment had two runs, and therefore, eight replicates were assessed. Thirty-three L1 larvae of $C$. riparius were introduced into test beakers containing the respective treatment and dechlorinated tap water. Feeding was carried out daily by adding $16 \pm 1 \mathrm{mg}$ fine ground fish flakes (mixture of 50\% TetraMin ${ }^{\circledR}$ and $50 \%$ TetraPhyll ${ }^{\circledR}$ ) dissolved in water to each beaker (corresponding to $0.48 \mathrm{mg} /$ day/larvae, assuming a $100 \%$ survival rate of introduced larvae). From the second day onwards, the beakers were aerated through a glass Pasteur pipette. Sediment was exchanged two times during the test at 10 and 17 days.

The survival of the third (L3) and fourth (L4) instar larvae was monitored at 10 and 17 days after oviposition, during the exchange of the sediment. This approach made it possible to distinguish between early and late larval mortality; and furthermore to differentiate between mortality and disturbances of the emergence process, both resulting in a reduced emergence rate. At the same time, locomotor and ventilatory activities of 12 larvae per treatment (randomly selected animals from each of the four replicates) were also measured for $2 \mathrm{~h}$ with the $\mathrm{MFB}^{\circledR}{ }^{\circledR}$ in dechlorinated tap water. After those measurements, the larvae were transferred into new beakers with fresh sediment and water. When emergence started, the number and sex of midges emerging were determined daily.
To detect changes in development time, for each concentration, the developmental rate was calculated according to OECD (2004a, b). Temperature, $\mathrm{pH}$, conductivity and dissolved oxygen saturation were measured in the water before introducing the larvae and after test termination.

\subsection{Assessment of benthos organisms}

Counting and identification of macrozoobenthos organisms in the pulp deposit, as well as in the lake reference sediment, was performed using a stereomicroscope (Leica MZ 6, Leica Microsystems GmbH, Wetzlar, Germany) according to various identification keys (e.g. Glöer et al. 1992; Studemann et al. 1992; Wichard et al. 1995; Waringer and Graf 1997). Species were determined down to the genus level. In total, eight samples of the pulp deposit and eight samples of the reference sediment were analysed as follows: Each sample was mixed; six aliquots were taken and the wet weight of each aliquot determined. In each of those aliquots (mean wet weight $49.2 \mathrm{~g}$, corresponding to $20.8 \mathrm{~g}$ dry weight), the macrozoobenthos were classified. Afterwards, in order to be able to compare the results of the different samples, macrozoobenthos data were extrapolated from the sample aliquots to the whole sample. Therefore, one aliquot of each sample was dried, the dry weight measured and extrapolated to $1 \mathrm{~kg}$ and $1 \mathrm{~m}^{3}$ of dry weight for the whole sample. The organism numbers in the aliquots were subsequently extrapolated to organisms in $1 \mathrm{~kg}$ and $1 \mathrm{~m}^{3}$.

\subsection{Data analysis}

Where a dose-response curve could be fitted, the results were integrated and reported as $\mathrm{EC}_{50}$ and/or $\mathrm{EC}_{x}$ (i.e. the concentration at which the sample tested induced a $50 \%$ or $x \%$ effect (e.g. growth limitation) at the end of the test compared with the control) using a sigmoidal dose-response model with a variable slope (GraphPad Prism 5; GraphPad Software Inc., CA, USA). Values for effect concentrations are reported with $95 \%$ confidence intervals.

Additionally, the concentration at which no significant effect was detected (no observed effect concentration (NOEC)) and the concentration at which a significant effect was first observed (lowest observed effect concentration (LOEC)) were calculated. At present, the use of NOEC and LOEC values is under discussion (e.g. Landis and Chapman 2011; van Dam et al. 2012); however, we decided to report them, as they are still important for environmental risk assessment.

If the data were normally distributed (D'Agostino \& Pearson omnibus normality test) (for $C$. dubia assay), a oneway analysis of variance was performed followed by a Dunnett's test with a comparison of the exposure treatments versus the control treatment (GraphPad Prism 5; GraphPad 
Software Inc., CA, USA). If no normally distributed data were available (for the assays with $G$. fossarum, $C$. riparius and $P$. subcapitata), a nonparametric Kruskal-Wallis test was performed, followed by a Dunn's test with a comparison of the exposure treatments versus the control treatment. In the assay with $C$. riparius, we first tested whether the data from the lake reference sediment and the quartz control sediment were identical (Kruskal-Wallis test; Graph Pad Prism 5.0). Since there was no statistical difference, the reference treatments were combined for graphs and further statistical testing.

\section{Results}

\subsection{Chemical analysis}

An overview of the chemical analysis results is given in Table 1. For metals, in the pulp deposit, high concentrations of $\mathrm{Al}\left(26,700 \mathrm{mg} \mathrm{kg}^{-1}\right)$ and $\mathrm{Ba}\left(4320 \mathrm{mg} \mathrm{kg}^{-1}\right)$ were detected as well as $\mathrm{Cd}\left(2.58 \mathrm{mg} \mathrm{kg}^{-1}\right)$. For the organic compounds, PCBs were found at a total concentration of $16.2 \mathrm{mg} \mathrm{kg}^{-1}$ and 16 PAHs amounting to $21.5 \mathrm{mg} \mathrm{kg}^{-1}$, as well as EOX at a total concentration of $12.3 \mathrm{mg} \mathrm{kg}^{-1}$ and $897 \mathrm{mg} \mathrm{kg}^{-1}$ for hydrocarbons (C10-C40).

Concentrations in the pulp deposit pore water were substantially lower, with $6 \mu \mathrm{g} \mathrm{l}^{-1}$ EOX and $13 \mathrm{mg} \mathrm{l}^{-1}$ DOC. PCBs were found at a total concentration of $4.98 \mu \mathrm{g} \mathrm{l}^{-1}$, whereas concentrations in the reference sediment pore water were relatively low with $3 \mathrm{mg}^{-1}$ DOC, $1 \mu \mathrm{g}^{-1}$ EOX and $0.18 \mu \mathrm{g}^{-1}$ PCBs. Ammonium was elevated in both pore water types, with $2.87 \mathrm{mg} \mathrm{l}^{-1}$ pulp deposit pore water and $2.01 \mathrm{mg} \mathrm{l}^{-1}$ lake sediment pore water. In the lake water sample, all metals and PCBs were below their respective limit of detection. Other abiotic parameters were below the allowed limits in the Swiss "Altlastenverordnung-ordinance of contaminated sites" (Schweizerischer Bundesrat 1998).

\subsection{Bioassays}

\subsubsection{Abiotic parameters}

In general, the physico-chemical parameters of water and sediment were suitable for the survival and reproduction of the respective test organisms. In the reproduction assay with C. dubia, the $\mathrm{pH}$ ranged from 7.2-7.9 at the onset of the test and 7.9-8.2 during the test. Conductivity was between 280 $520 \mu \mathrm{S} \mathrm{cm}^{-1}$ at the start of the test and 282-436 $\mu \mathrm{S} \mathrm{cm}^{-1}$ during the test, and dissolved oxygen ranged from $7.2-7.9 \mathrm{mg} \mathrm{O}_{2} 1^{-1}$ at the start of the test to 8.0 to $8.2 \mathrm{mg} \mathrm{O}_{2} \mathrm{l}^{-1}$ during the test. In the extended whole-lifecycle test with $C$. riparius, the measured abiotic parameters such as temperature, oxygen content, conductivity and $\mathrm{pH}$ varied due to the different character of the tested sediments and dilutions, but they did not exceed the mandatory range given in the OECD guidelines (OECD 2004a, b). Therefore, the test can be considered valid.

\subsubsection{Results of bioassays}

Algae test with P. subcapitata Neither the pulp nor lake sediment had an effect on the effective quantum yield of photosynthesis. The values after $2 \mathrm{~h}$ exposure varied between +4.1 and $-5.2 \%$ enhancement/inhibition (data are provided in Online resource 1). After $24 \mathrm{~h}$, no significant change in the growth rate could be measured; the values ranged from +21.0 to $-22.1 \%$ enhancement/inhibition. This effect was independent of the dilution level. No clear doseresponse relationship could be observed for any of the parameters.

Acute test with G. fossarum No effect on movement activity in terms of avoidance of $G$. fossarum was detected after $2 \mathrm{~h}$. After $20 \mathrm{~h}$, movement activity was significantly higher $(p<0.05)$ than the control and lake water in selected dilutions of the pulp deposit pore water (12.5\%); however, this was not the case at $25 \%$ dilution (Fig. 1, data are provided in Online Resource 2). No mortality was observed in the treatments during the 48 -h test period.

Chronic reproduction assay with C. dubia Figure 2 shows the population growth of $C$. dubia after 8 days exposure to the control, lake water, lake sediment and pulp deposit pore water at different dilution levels. When exposed to lake water, the cladocerans showed neither a change in mortality $(100 \%$ survival) nor inhibition in population growth in comparison to the control. There was, in fact, a slight (nonsignificant) increase in population growth. For the lake sediment pore water, all tested concentrations induced a mild, non-significant stimulation of population growth when compared with the control.

When exposed to the pulp deposit pore water at day 7 , no mortality in the parental generation was observed, however, their development was clearly delayed. In the undiluted solution, no population growth occurred at all. In many cases, the young mothers were able to produce a small amount of eggs (two to three broods), but the embryos were unable to develop normally and did not hatch, which significantly affected reproduction (no offspring after 7 days exposure). In contrast, females in the control treatment produced 13-22 eggs per female with a total production of 233 newborn offspring from 14 females. After 8 days, the egg production in the pulp deposit treatment was four to eight per female of which three hatched compared with 17-33 eggs per female in the control treatment with a total of 356 offspring from 14 females. The effect concentrations 
Table 1 Measured concentrations for metals, polychlorinated biphenyls (PCBs) and polycyclic aromatic hydrocarbons (PAHs), $\mathrm{N}$ - and P-compounds and organic sum parameters
$T S$ total solid, n.m. not measured

\begin{tabular}{|c|c|c|c|c|}
\hline Substance group & Lake water & $\begin{array}{l}\text { Lake reference } \\
\text { sediment pore water }\end{array}$ & $\begin{array}{l}\text { Pulp deposit } \\
\text { pore water }\end{array}$ & $\begin{array}{l}\text { Pulp } \\
\text { deposit }\end{array}$ \\
\hline \multicolumn{5}{|l|}{ Metals (mg $\mathrm{l}^{-1}$ or $\mathrm{mg} \mathrm{kg}^{-1} \mathrm{TS}$ ) } \\
\hline Aluminium & n.m. & n.m. & n.m. & 26,700 \\
\hline Antimony & $<0.005$ & $<0.005$ & $<0.005$ & 7.6 \\
\hline Arsenic & $<0.005$ & $<0.005$ & $<0.005$ & 6.9 \\
\hline Barium & n.m. & n.m. & n.m. & 4,320 \\
\hline Cadmium & $<0.0001$ & 0.0003 & 0.0049 & 2.58 \\
\hline Chromium & $<0.002$ & 0.005 & 0.032 & 52.4 \\
\hline Chromium-VI (solved) & $<0.001$ & $<0.001$ & $<0.001$ & n.m. \\
\hline Cobalt & $<0.002$ & $<0.002$ & $<0.002$ & 5.8 \\
\hline Copper & $<0.002$ & 0.017 & 0.025 & 438 \\
\hline Lead & $<0.001$ & 0.01 & 0.011 & 224 \\
\hline Mercury & $<0.0002$ & $<0.0002$ & $<0.0002$ & 1.15 \\
\hline Molybdenum & n.m. & n.m. & n.m. & 3.48 \\
\hline Nickel & $<0.002$ & 0.003 & 0.018 & 25.5 \\
\hline Silver & $<0.005$ & $<0.005$ & $<0.005$ & n.m. \\
\hline Thallium & n.m. & n.m. & n.m. & $<0.05$ \\
\hline Tin & $<0.002$ & 0.014 & 0.008 & 429 \\
\hline Zinc & $<0.010$ & $<0.010$ & $<0.010$ & 451 \\
\hline \multicolumn{5}{|l|}{$\operatorname{PCB}\left(\mu \mathrm{g}^{-1} ; \mathrm{mg} \mathrm{kg}^{-1} \mathrm{TS}\right)$} \\
\hline PCB 28 & $<0.002$ & 0.005 & 0.194 & 0.32 \\
\hline PCB 52 & $<0.002$ & 0.004 & 0.114 & 0.24 \\
\hline PCB 101 & $<0.002$ & 0.007 & 0.179 & 0.56 \\
\hline PCB 118 & $<0.002$ & 0.007 & 0.1 & 0.31 \\
\hline PCB 138 & $<0.002$ & 0.012 & 0.293 & 1.04 \\
\hline PCB 153 & $<0.002$ & 0.009 & 0.243 & 0.96 \\
\hline PCB 180 & $<0.002$ & 0.005 & 0.135 & 0.65 \\
\hline PCB sum & $<0.05$ & 0.18 & 4.98 & 16.2 \\
\hline \multicolumn{5}{|l|}{ PAH (mg kg $\left.{ }^{-1} \mathrm{TS}\right)$} \\
\hline Naphthalene & n.m. & n.m. & n.m. & 0.29 \\
\hline Acenaphthylene & n.m. & n.m. & n.m. & 0.17 \\
\hline Acenaphthene & n.m. & n.m. & n.m. & 0.13 \\
\hline Fluorene & n.m. & n.m. & n.m. & 0.29 \\
\hline Phenanthrene & n.m. & n.m. & n.m. & 2.63 \\
\hline Anthracene & n.m. & n.m. & n.m. & 0.84 \\
\hline Fluoranthene & n.m. & n.m. & n.m. & 1.7 \\
\hline Pyrene & n.m. & n.m. & n.m. & 2.9 \\
\hline Chrysene & n.m. & n.m. & n.m. & 1.92 \\
\hline Benz(a)anthracene & n.m. & n.m. & n.m. & 2.32 \\
\hline Benzo(b)fluoranthene & n.m. & n.m. & n.m. & 2.34 \\
\hline Benzo(k)fluoranthene & n.m. & n.m. & n.m. & 0.91 \\
\hline Benzo(a)pyrene & n.m. & n.m. & n.m. & 1.83 \\
\hline Indeno(1,2,3-cd)pyrene & n.m. & n.m. & n.m. & 1.21 \\
\hline Dibenzo(a,h)anthracene & n.m. & n.m. & n.m. & 0.35 \\
\hline Benzo(ghi)perylene & n.m. & n.m. & n.m. & 1.67 \\
\hline PAH sum & n.m. & n.m. & n.m. & 21.5 \\
\hline \multicolumn{5}{|l|}{$\mathrm{N}$ - and P-compounds ( $\mathrm{mg} \mathrm{l}^{-1}$ ) } \\
\hline Ammonium & $<0.01$ & 2.01 & 2.87 & n.m. \\
\hline Nitrite & $<0.005$ & 0.012 & 0.03 & n.m. \\
\hline \multicolumn{5}{|l|}{ Organic sum parameters } \\
\hline $\mathrm{DOC}\left(\mathrm{mg} \mathrm{l}^{-1} \mathrm{C}\right)$ & 1.3 & 3.0 & 13 & \\
\hline $\operatorname{EOX}\left(\mu \mathrm{g} \mathrm{l}^{-1}\right.$ or $\left.\mathrm{mg} \mathrm{kg}^{-1} \mathrm{TS} \mathrm{Cl}\right)$ & $<1$ & 1 & 6 & 12.3 \\
\hline
\end{tabular}




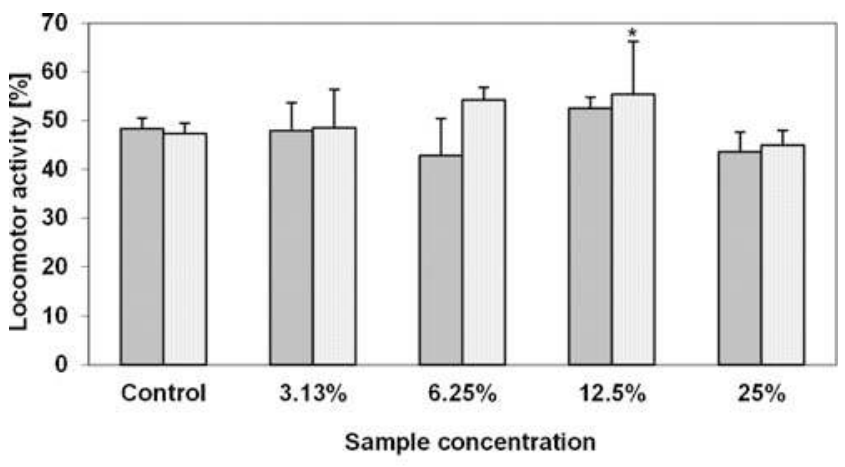

口Lake reference sediment pore water $\quad$ QPulp deposit pore water

Fig. 1 Locomotor activity ( $\%$; means \pm SD) of $G$. fossarum after $20 \mathrm{~h}$ exposure to different dilutions of lake reference sediment pore water and pulp deposit pore water ( $n=5$ individuals per treatment). Significant difference to control treatment $* p<0.05$ (Dunn's test)

$\left(\mathrm{EC}_{50}\right)$ after 7 and 8 days exposure were $26.05 \%$ (CI 17.4 $39.0 \%$ ) and $28.08 \%$ (CI $18.9-41.8 \%$ ) of the native sample, with a NOEC and LOEC at $6.25 \%$ and $12.5 \%$ sample concentrations, respectively (minimal significant difference $=-32.3 \%$ after 7 days; $-34.7 \%$ after 8 days). Data are provided in Online resource 3.

Extended whole-life cycle test with C. riparius mortality No significant difference in the survival rate was observed between the quartz sediment control and the lake sediment control. In contrast, the survival rate of $C$. riparius (10 and 17 days after oviposition) exposed to $100 \%$ pulp deposit was significantly reduced compared with the $100 \%$ lake sediment (Fig. 3; data are provided in Online resource 4).

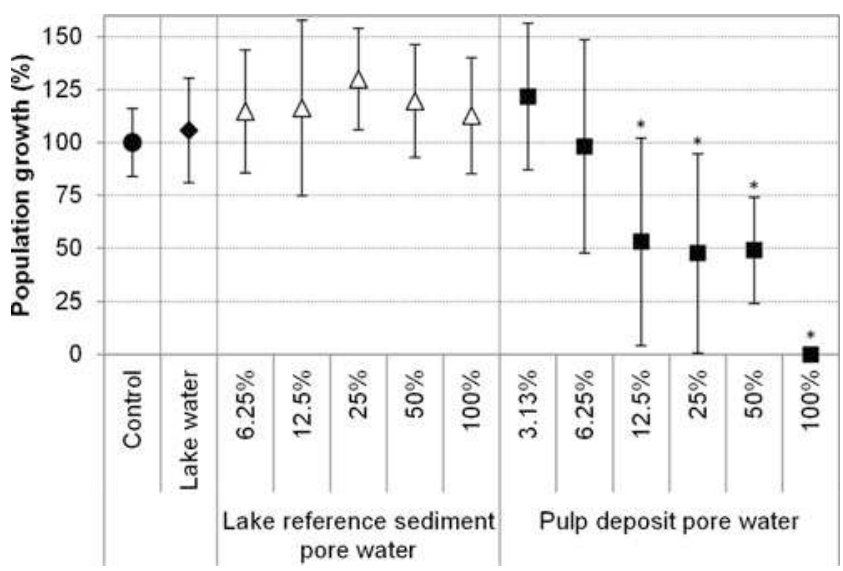

Fig. 2 Population growth of $C$. dubia after 8 days exposure to three different samples and sample dilutions (shown in percent relative to control). Values are means \pm SD (11-14 replicates per treatment each with one adult $C$. dubia). Significant difference to control treatment ${ }^{*} p<0.05$ (Dunnett's test)

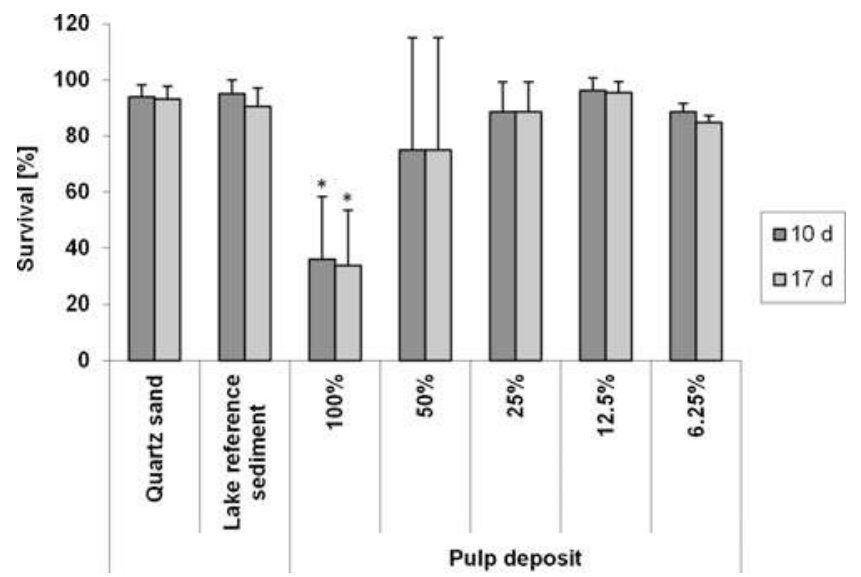

Fig. 3 Average survival rate of C. riparius exposed to different sediments and sediment dilutions 10 and 17 days after oviposition. Values are means $\pm \mathrm{SD}$ ( $n=4$ replicates per treatment each with 33 larvae, lake reference sediment with $n=8$ replicates). Significance in comparison to lake reference sediment $* p<0.05$ (Dunn's test)

Behaviour Ten days after oviposition, there were no significant differences in the locomotor and ventilatory activities of $C$. riparius exposed to quartz sediment, lake reference sediment and different pulp deposit dilutions. However, 17 days after oviposition, a significant reduction in locomotor activity of $C$. riparius exposed to pulp deposit concentrations of $25 \%$ up to $100 \%$ compared with the lake sediment was determined (Fig. 4; data are provided in Online Resource 5), whereas no differences in locomotor activity between quartz sand and lake sediment treatment occurred.

Emergence Since the percentage of emerged chironomids exposed to quartz sediment as the internal control was above $70 \%$, the test was considered valid according to OECD

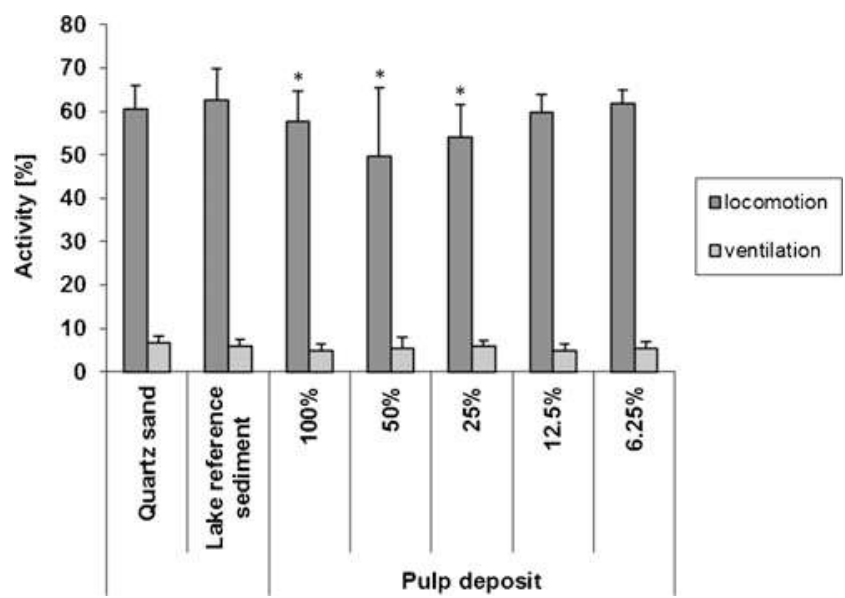

Fig. 4 Locomotor and ventilatory activity (\%; means \pm SD) of $C$. riparius 17 days after oviposition exposed to three different sediments and sediment dilutions during $2 \mathrm{~h}$ of behaviour measurement $(n=11$ larvae per treatment, lake reference sediment $n=28$ larvae per treatment). Significant difference compared to lake sediment $* p<0.05$ (Dunn's test) 
Fig. 5 Mean cumulative numbers of emerged C. riparius imagos exposed to different sediments and sediment dilutions ( $n=4$ replicates per treatment, lake reference sediment with $n=8$ replicates). Number of emerged $C$. riparius was significantly lower in the $100 \%$ pulp deposit treatment compared with lake sediment $p<0.05$ (Dunn's test)

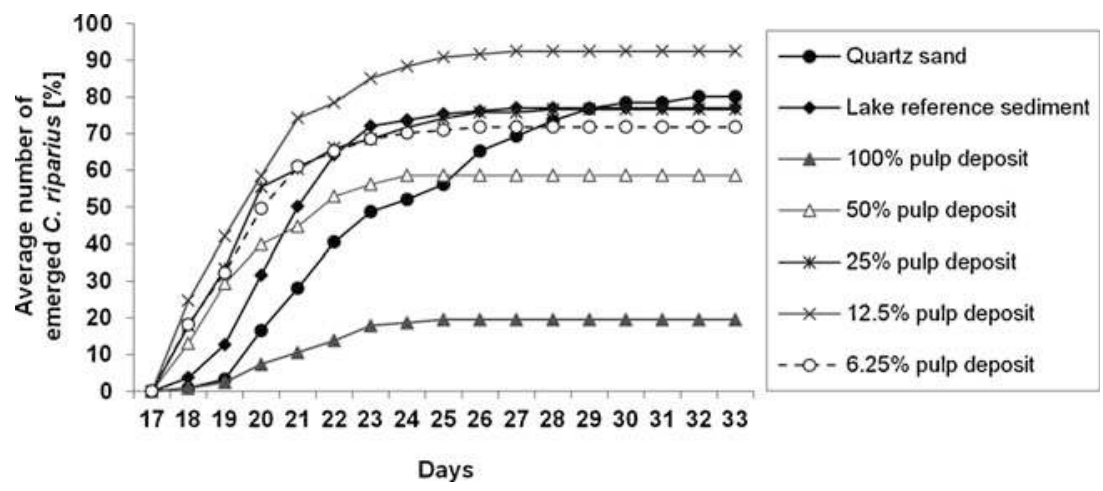

218/219 (OECD 2004a, b). No significant difference in the number of emerged $C$. riparius from the quartz sediment and the lake sediment was detected. The number of emerged $C$. riparius exposed to $100 \%$ pulp deposit was significantly reduced compared with the lake sediment (Fig. 5; data are provided in Online resources 6 and 7).

Developmental rate The development of $C$. riparius in the quartz sediment was significantly elongated compared with the lake sediment. Therefore, the developmental rate of chironomids in the pulp deposit and its dilutions was compared solely with their developmental rate in the lake sediment. As for the other investigated endpoints, no such difference between quartz and lake sediment was found, and thus this exception does not appear to be a significant problem. The developmental rate of C. riparius exposed to $100 \%$ pulp deposit and to its lowest dilution $(1: 2,50 \%)$ was significantly decreased compared with the lake sediment. The assumed sex ratio of 1:1 did not deviate significantly from the actual sex distribution in any of the replicates. For all endpoints, the results for the blank controls fulfilled the validity criteria, thus allowing the whole series to be validated.

\subsection{Biodiversity of macrozoobenthos organisms}

When examining the macrozoobenthos organisms, higher numbers of chironomids and tubificids were present in the pulp deposit compared with the reference lake sediment (472 versus 278 chironomids $\mathrm{kg}^{-1}$ dry weight (dw) and 176 versus 28 tubificids $\mathrm{kg}^{-1} \mathrm{dw}$, respectively). In contrast, in the lake sediment, significantly higher numbers of copepods (Family Cyclopidae) and water mites (Family Hydracarina, genus Unionicola) were observed. Overall, in the pulp deposit, more individuals of the macrozoobenthic species were present compared with the reference sediment; however, this was mainly driven by a higher occurrence of the relatively pollution-tolerant chironomid larvae and tubificid worms (data are provided in Online Resource 8).

\section{Discussion}

The integrity of ecosystems can be influenced by stressors at many different levels. However, many studies have focused on the direct effects of contaminants on single species. In the present study, a sediment quality triad approach, combining chemical data with single species toxicity tests and ecological information on the macrozoobenthos community composition, was applied in order to assess in an integrative way the potential hazard of pulp deposit in a Swiss lake for aquatic organisms. To our knowledge, this is the first pulp deposit which has been analysed using such an approach. Therefore, we aimed to propose an appropriate set of bioassays for this kind of contamination, representing the different parts of the ecosystem: such as primary producers, primary consumers and decomposers. In general, the present study showed that the assessed pulp deposit should be classified as toxic.

\subsection{C. riparius as suitable test organism for pulp deposit assessment}

C. riparius, which in our study exhibited a high sensitivity to the pulp deposit, was to our knowledge used for the first time in a whole sediment study with a pulp or paper mill deposit. Amongst other life-cycle traits, the pulp deposit elicited effects on the reproduction and growth of the organisms, even down to low pulp deposit concentrations (12.5\%). In the few other studies assessing sediment influenced by pulp and paper mill effluent (e.g. Pellinen and Soimasuo 1993; Sibley et al. 1997), the effects were less severe compared with the present study. The enhanced as well as reduced growth of $C$. riparius were observed in other studies (e.g. Pellinen and Soimasuo 1993; Sibley et al. 1997), as was no detectable effects on growth (e.g. Sibley et al. 1997; Rosa et al. 2010). Instead, a high mortality by exposure to elutriates or pore water of the same sediment was detected (Sibley et al. 1997). As the reproduction of Daphnia magna and Tubifex tubifex were enhanced when in proximity to the effluent site, nutrients and ammonium in the pore water might also have been responsible for those effects. 
The most sensitive endpoints in the whole-life-cycle test with $C$. riparius were locomotor activity and emergence, which is in accordance with earlier studies. In single or mixture toxicity studies using C. riparius, the endpoints of larval development, production and survival (Pascoe et al. 1989), as well as larval locomotor activity, hsp70 protein level, survival and emergence of adults (Langer-Jaesrich et al. 2010a), were the most sensitive.

An inversion of the developmental rate in pure quartz sediment, with a significant elongation compared with the lake reference sediment as detected in the present study, was previously observed (Langer-Jaesrich, unpublished data). It can be assumed that, in addition to the lower proportion of organic matter in the sediment, the absence of microorganisms (which can present an additional food source) could also influence the development time.

\subsection{Locomotor activity as a sensitive endpoint}

The toxicity parameter locomotor activity proved to be especially sensitive in the present study, with effects being observed in G. fossarum and C. riparius in $12.5 \%$ and $25 \%$ sample concentrations, respectively. Behavioural responses are very relevant effect parameters and can occur earlier and at lower concentrations than the onset of effects on the survival or other sublethal effects (e.g. Beitinger 1990; Gerhardt 2007; Hellou 2011). Effects of pollutants on the behaviour of organisms can entail various other effects - inter- as well as intraspecific - such as a reduced ability to escape predators or catch prey (predator-prey relationship) (e.g. Clements et al. 1989; Langer-Jaesrich et al. 2010b) or impaired social or mating behaviour (e.g. McCahon and Pascoe 1988; Pascoe et al. 1989; Musko et al. 1990; Baird et al. 2007). In G. fossarum, a higher locomotor activity compared with the reference water was determined. This can indicate an escape response, which is often observed as a preliminary reaction to pollutants (Gerhardt 1999; Hellou 2011) and which has been found in various species, e.g. in Daphnia magna exposed to contaminated drinking water (Gerhardt et al. 2003), or in the amphipod Corophium volutator exposed to the fungicide chlorothalonil (Hellou et al. 2009). The decreased activity in C. riparius is often linked to narcosis (Drummond and Russom 1990) and has been observed earlier in amphipods as well as water fleas, chironomids and other species (Gerhardt et al. 2003; De Lange et al. 2006a; Langer-Jaesrich et al. 2010a).

\subsection{Detectable effects on algae}

Algae, despite their high sensitivity in previous studies (e.g. Bailey and Young 1997; Rosa et al. 2010) in which cell number/growth after $72 \mathrm{~h}$ was partially more sensitive than C. dubia reproduction (Bailey and Young 1997), did not display toxicity at concentrations of up to $25 \%$ pulp deposit pore water in the present study. Reasons for this might be the lower pore water concentration of max. $25 \%$; however, LOECs for $C$. dubia reproduction and growth and $C$. riparius locomotor activity were $12.5 \%$ pulp deposit pore water and $25 \%$ pulp deposit, respectively. The mild stimulation of growth which was partially observed at 12.5 and $25 \%$ sample concentrations may result from the increased nutrient availability in the samples compared with the control treatment.

\subsection{The role of chronic assays in pulp deposit assessment}

Overall, as expected, the effects were most severe in the chronic assays, where $C$. riparius and $C$. dubia displayed a similar sensitivity. Despite the equal sensitivity of these two chronic assays, we consider both important since they provide different information on the effect of toxicity on the life cycle. However, if due to cost reasons one bioassay has to be selected, the C. dubia assay gives valuable results, as shown in previous studies (e.g. DeGraeve et al. 1992; Costan et al. 1993; McKinney and Wade 1996). The choice of relevant test system also should be done according to the aim of the investigation; if toxicity in the water has to be assessed then C. dubia is preferable, while if the toxicity of the sediment has to be assessed then $C$. riparius is preferable.

\subsection{Correlation between chemical contamination} and bioassay results

Setting chemical analysis into this context leads to speculations on the possible contributions of distinct compounds to the observed biological effects. According to the chemical analysis, the main components in the deposit were metals such as Cd, PCBs, PAHs and EOXs. Table 2 gives an overview of selected toxicity data from the literature for these substance groups.

Cadmium (Cd) The measured Cd concentrations (pulp deposit, $2.58 \mathrm{mg} \mathrm{kg}^{-1}$; pulp deposit pore water, $4.9 \mu \mathrm{g} \mathrm{l}^{-1}$ ) were partly above the effect concentrations in the literature for $C$. dubia and C. riparius but not for P. subcapitata and Gammarus pulex. Bioconcentration in single-celled green algae occurred with factors of 28-78 (Sofyan et al. 2006).

Polychlorinated biphenyls (PCBs) Measured concentrations of PCBs in the pulp deposit $\left(16.2 \mathrm{mg} \mathrm{kg}{ }^{-1}\right)$ and in the pulp deposit pore water $\left(4.98 \mu \mathrm{g} \mathrm{l}^{-1}\right)$ were high enough to potentially elicit effects on the water flea as well as on chironomids but not on freshwater algae and amphipods. Additionally, PCBs have a high bioaccumulation potential with a maximal enrichment of 4,190-336,000 compared with the surrounding medium for crustaceans and chironomids. The accumulation of PCBs increases with increasing chlorination. 
Table 2 Selected toxicity data from the literature for the main substance groups present in the pulp deposit

\begin{tabular}{|c|c|c|c|c|c|c|}
\hline Substance & $\begin{array}{l}\text { Organism } \\
\text { group }\end{array}$ & Test organism & Endpoint & Value & & Reference \\
\hline \multicolumn{7}{|c|}{ Cadmium (Cd) (measured: $2.58 \mathrm{mg} \mathrm{kg}^{-1}$ in pulp deposit; $4.5 \mu \mathrm{g} \mathrm{l^{-1 }}$ in pulp deposit pore water) } \\
\hline $\mathrm{Cd}$ & Algae & P. subcapitata & $24 \mathrm{~h} \mathrm{EC}_{50}$ (growth) & $104-713$ & $\mu \mathrm{g} 1^{-1}$ & $\begin{array}{l}\text { Van der Heever and } \\
\text { Grobbelaar (1996) }\end{array}$ \\
\hline $\mathrm{Cd}$ & Algae & P. subcapitata & $\mathrm{BCF}$ & $28-78$ & & Sofyan et al. (2006) \\
\hline $\mathrm{Cd}$ & Crustacean & C. dubia & $\begin{array}{l}7 \text { days } \mathrm{EC}_{50} \\
\text { (reproduction) }\end{array}$ & 7.24 & $\mu \mathrm{g} 1^{-1}$ & Sofyan et al. (2007) \\
\hline $\mathrm{Cd}$ & Crustacean & Gammarus pulex & 2 days $L_{50}$ & $19-4,700$ & $\mu \mathrm{g} 1^{-1}$ & $\begin{array}{l}\text { McCahon and Pascoe } \\
\text { (1988) }\end{array}$ \\
\hline $\mathrm{CdCl} 2$ & Chironomid & C. riparius & $\begin{array}{l}14 \text { days } \mathrm{EC}_{20} \\
\text { (larval growth) }\end{array}$ & 8.1 & $\mu \mathrm{g} 1^{-1}$ & Niederlehner (1984) \\
\hline $\mathrm{CdCl} 2$ & Chironomid & C. riparius & 14 days $\mathrm{LC}_{50}$ & 5.4 & $\mu \mathrm{g} 1^{-1}$ & Niederlehner (1984) \\
\hline \multicolumn{7}{|c|}{ Polychlorinated biphenyls (PCBs) (measured, $16.2 \mathrm{mg} \mathrm{kg}^{-1}$ in pulp deposit; $4.98 \mu \mathrm{g}^{-1}$ in pulp deposit pore water) } \\
\hline Various PCBs & Algae & P. subcapitata & 2 days $\mathrm{EC}_{50}$ (growth) & $14-241$ & $\mu \mathrm{g} 1^{-1}$ & Mayer et al. (1998) \\
\hline PCB 153 & Crustacean & Daphnia magna & $\begin{array}{l}21 \text { days } \\
\text { reproduction }\end{array}$ & $12.5-25$ & $\mu \mathrm{g} 1^{-1}$ & Nakari and Huhtala (2008) \\
\hline PCB $1242+1254$ & Crustacean & Gammarus pseudolimnaeus & 4 days $\mathrm{LC}_{50}$ & $10-210$ & $\mu \mathrm{g} 1^{-1}$ & $\begin{array}{l}\text { Mayer and Ellersieck } \\
\text { (1986) }\end{array}$ \\
\hline PCB 1254 (Arochlor) & Crustacean & G. pseudolimnaeus & 4 days $\mathrm{BCF}$ & 24,000 & & $\begin{array}{l}\text { Sanders and Chandler } \\
\text { (1972) }\end{array}$ \\
\hline Various PCBs & Chironomid & Chironomus tentans & 20 days survival & 8.7 & $\mathrm{mg} \mathrm{kg}^{-1}$ & Burton (2003) \\
\hline Various PCBs & Chironomid & C. tentans & $\mathrm{BCF}$ & $4,190-336,000$ & & Novak et al. (1990) \\
\hline \multicolumn{7}{|c|}{ Polyaromatic hydrocarbons (PAHs) (measured, $25.1 \mathrm{mg} \mathrm{kg}^{-1}$ in pulp deposit; $\mathrm{n} . \mathrm{m}$. in pulp deposit pore water) } \\
\hline Anthracene & Algae & P. subcapitata & $\begin{array}{l}24 \text { h EC50 } \\
\text { (photosynthesis) }\end{array}$ & $3.3-24$ & $\mu \mathrm{g} 1^{-1}$ & Gala and Giesy (1992) \\
\hline Pyrene & Algae & P. subcapitata & 1 day $\mathrm{BCF}$ & $\begin{array}{l}2,120- \\
36,300\end{array}$ & & Casserly et al. (1983) \\
\hline Fluoranthene & Crustacean & Gammarus locusta & 2 days $\mathrm{LC}_{50}$ & 42.71 & $\mu \mathrm{g} 1^{-1}$ & Sanz-Lazaro et al. (2008) \\
\hline Penanthrene & Crustacean & G. locusta & 2 days $\mathrm{LC}_{50}$ & 147.64 & $\mu \mathrm{g} 1^{-1}$ & Sanz-Lazaro et al. (2008) \\
\hline Fluoranthene & Crustacean & C. dubia & 7 days $\mathrm{EC}_{50}$ & 28.5 & $\mu \mathrm{g} 1^{-1}$ & Oris et al. (1991) \\
\hline Benzo(a)pyren & Crustacean & Daphnia sp. & $6 \mathrm{~h} \mathrm{BCF}$ & $838-2,745$ & & Leversee et al. (1983) \\
\hline Benzo(a)pyren & Crustacean & Daphnia sp. & 3 days $\mathrm{BCF}$ & 134,248 & & Lu et al. (1977) \\
\hline $\begin{array}{l}\text { Mixture of } \\
\text { phenanthrene, } \\
\text { fluoranthene and } \\
\text { benzo(k)fluoranthene }\end{array}$ & Chironomid & C. riparius & 10 days $\mathrm{LC}_{50}$ & 11.51 & $\mathrm{mg} \mathrm{kg}^{-1}$ & Verrhiest et al. (2001) \\
\hline Fluoranthene & Chironomid & C. riparius & $\begin{array}{r}28 \text { days LOEC } \\
\text { (emergence) }\end{array}$ & 88 & $\mu \mathrm{g}^{-1}$ & $\begin{array}{l}\text { Stewart and Thompson } \\
\text { (1995) }\end{array}$ \\
\hline Fluoren & Chironomid & C. riparius & $\begin{array}{r}30 \text { days LOEC } \\
\text { (emergence) }\end{array}$ & 600 & $\mu \mathrm{g} 1^{-1}$ & Finger et al. (1985) \\
\hline Fluoranthene & Chironomid & C. tentans & 10 days $\mathrm{BCF}$ & 3.4 & & Schuler et al. (2004) \\
\hline Pyrene & Chironomid & C. riparius & 2.08 days BCF & $713-1,217$ & & Wildi et al. (1994) \\
\hline
\end{tabular}

Data were compiled from the EPA Ecotox database (http://cfpub.epa.gov/ecotox: accessed: 17 March 2013) based on the test species, endpoints and duration in the present study

n.m. not measured

Polyaromatic hydrocarbons (PAHs) Concentrations of PAHs (pulp deposit, $25.1 \mathrm{mg} \mathrm{kg}^{-1}$ of 15 PAHs in total; pulp deposit pore water, not measured) were above the effect concentrations for aquatic organisms such as freshwater algae, various amphipod species and water fleas. Additionally, effects on chironomids can be expected according to the literature. Similar to PCBs, PAHs exhibit a high bioaccumulation potential for algae, water fleas and chironomids.

Extractable organically bound halogens (EOXs) The fourth and last major chemical group detected in high concentrations were EOXs (pulp deposit, $12.3 \mathrm{mg} \mathrm{kg}^{-1}$; pulp deposit pore water, $6 \mu \mathrm{g} \mathrm{l}^{-1}$ EOX). However, details for the toxic 
potential of EOX for aquatic organisms vary greatly in the literature. Some studies found no or only a weak correlation of increasing EOX values with toxicity, e.g. for the chronic exposure of C. dubia to EOX of a laundry (Ong et al. 1996) or for algae and water fleas exposed to wastewater from the pulp and paper mill industry (Aschacher 1992). Other studies showed a certain coherence/correlation of the EOX values and toxicity for bacteria, algae and/or water fleas (Gellert 2000; Emmanuel et al. 2004). O'Connor et al. (1993) judged that the group parameter for chlorinated organic compounds was not a good indicator of the toxicity of treated wastewater.

Considering all this information from the literature, it is likely that the observed toxicity is caused by the substance groups PCBs, PAHs and metals. The high bioaccumulation potential of PCBs and PAHs is especially important, as chronic effects might occur which can entail a threat to higher trophic levels such as primary and secondary consumers. The influence of EOX might also be possible, due to the high concentrations in the pulp deposit; however, it is rather uncertain due to the different aspects mentioned in the literature data.

When comparing the measured values for $\mathrm{Cd}, \mathrm{PCBs}$ and PAHs to the threshold effect concentrations (TECs) and probable effect concentrations (PECs) for sediment from the literature (MacDonald et al. 2000) ecotoxicological effects can also be assumed. A comparison of TEC and PEC values with measured concentrations (Table 3) reveals an exceedance of TEC values in the pulp deposit for all substances/substance groups and of PEC values for PCBs and PAHs.

\subsection{Potential effects on community level}

On a higher biological organisation level, the effects on single organisms can result in effects at the community level, e.g. of macrozoobenthos organisms. In the present study, a higher abundance of the relatively pollutant-tolerant chironomids and tubificides (Wildhaber and Schmitt 1998) was detected in the pulp deposit compared with the reference lake sediment. The high number of chironomids in the pulp deposit is in contrast to their high sensitivity to the deposit in the laboratory lifecycle assay. The reasons for this might be a (genetic)

Table 3 Threshold effect concentrations (TEC) and probable effect concentrations (PEC) from the literature (MacDonald et al. 2000) and measured concentrations for cadmium (Cd), polychlorinated biphenyls (PCBs) and polycyclic aromatic hydrocarbons (PAHs) (sum of $16 \mathrm{PAHs}$ measured)

\begin{tabular}{llll}
\hline Substance group & $\begin{array}{l}\text { TEC } \\
\left(\mathrm{mg} \mathrm{kg}^{-1}\right)\end{array}$ & $\begin{array}{l}\text { PEC } \\
\left(\mathrm{mg} \mathrm{kg}^{-1}\right)\end{array}$ & $\begin{array}{l}\text { Measured conc. } \\
\left(\mathrm{mg} \mathrm{kg}^{-1}\right)\end{array}$ \\
\hline $\mathrm{Cd}$ & 0.99 & 4.98 & 2.58 \\
PCBs & 0.0598 & 0.676 & 16.2 \\
PAHs & 1.61 & 22.8 & 21.5 \\
\hline
\end{tabular}

adaptation of the chironomids in the field to the pollution, which makes them more tolerant than organisms from the laboratory, such as reported for chironomids from metal polluted areas (Postma et al. 1995; Soeter et al. 2010). There might also be other Chironomus species present in the macrozoobenthos with different sensitivities than the $C$. riparius used in the bioassay. In earlier studies, a higher number of benthic and emerged insects in mesocosms exposed to pulp and paper mill effluent was detected as well as a higher biomass in periphyton assemblages, presumably related to nutrient enrichment due to the effluent rather than to effluent toxicity (Culp et al. 2003). However, in other studies, a high toxicity of sediments influenced by pulp mill effluent to various aquatic organisms was detected (Sibley et al. 1997) and the crustaceans G. fossarum and Asellus aquaticus avoided PAH-contaminated sediment (De Lange et al. 2006b). Generally, studies assessing the effects of pulp and paper mill effluent and/or deposits on macrozoobenthos communities are rare.

\section{Conclusions}

The applied set of bioassays revealed that it was suitable for detecting the hazard of a pulp deposit to aquatic organisms of various trophic levels, as it combines acute and chronic effects as well as two environmental compartments: water and sediment. In general, sediment-inhabiting organisms such as chironomids are most likely to be exposed to this deposit. Sensitive species might even avoid it. The information on the chemical composition of the deposit can, together with the effect data for relevant aquatic organisms, be used for a risk assessment of the respective site. Additionally, more ecosystem-relevant data can be gained with reasonable effort, by collecting information on the macrozoobenthos organisms present at the site under investigation in comparison to a reference site. With this information, possible risk mitigation measures can also be planned and the success of those measures assessed at appropriate time intervals.

Acknowledgements The authors would like to thank Alois Zwyssig from Eawag, Dübendorf, Switzerland, who performed the fundamental work that has enabled us to conduct this study.

\section{References}

AFNOR (2000) Water quality - determination of chronic toxicity to Ceriodaphnia dubia in 7 days. Population growth inhibition test. AFNOR NF T 90-376, Saint Denis: Association Française de Normalisation, France, $18 \mathrm{pp}$

Ahlf W (1995) Biotests an Sedimenten. In: Steinberg C, Bernhardt H, Klappner H (eds) Handbuch Angewandte Limnologie Teil Aquatische Ökotoxikologie. ecomed, Landsberg, Germany, pp 1-43 
Aschacher GP (1992) AOX and toxicity. Holzforsch Holzverw 6:101-103 Bailey HC, Young L (1997) A comparison of the results of freshwater aquatic toxicity testing of pulp and paper mill effluents. In: Hall ER, Colodey AG (eds) Proceedings of the 5th IAWQ International Symposium on Forest Industry Wastewaters. Vancouver, Canada, pp 305-313

Baird DJ, Burton GA, Culp JM, Maltby L (2007) Summary and recommendations from a SETAC Pellston workshop on in situ measures of ecological effects. Integr Environ Assess Manag 3:275-278

Beitinger TL (1990) Behavioral reactions for the assessment of stress in fishes. J Great Lakes Res 16:495-528

Bertoletti E, Araujo RPA, Zagatto PA, Gherardi-Goldstein E (1988) Toxicity evaluation of paper mill effluents. Water Sci Technol 20:191

Burton GA (2003) Assessment of in situ stressors and sediment toxicity in the Lower Housatonic River. Institute for Environmental Quality, Dayton, Ohio, USA, 127 pp

Casserly DM, Davis EM, Downs TD, Guthrie RK (1983) Sorption of organics by Selenastrum capricornutum. Water Res 17:15911594

Chapman PM (1986) Sediment quality criteria from the sediment quality triad: an example. Environ Toxicol Chem 5:957-964

Chapman PM, Hollert H (2006) Should the sediment quality triad become a tetrad, a pentad, or possibly even a hexad? J Soils Sediments 6:4-8

Chapman PM, Power EA, Burton GA (1992) Integrative assessments in aquatic ecosystems. In: Burton GA (ed) Sediment toxicity assessment. Lewis, Boca Raton, USA, pp 313-340

Clements WH, Cherry DS, Cairns J Jr (1989) The influence of copper exposure on predator-prey interactions in aquatic insect communities. Freshwater Biol 21:483-488

Costan G, Bermingham N, Blaise C, Ferard JF (1993) Potential ecotoxic effects probe (PEEP): a novel index to assess and compare the toxic potential of industrial effluents. Environ Toxicol Water Qual 8:115-140

Culp JM, Cash KJ, Glozier NE, Brua RB (2003) Effects of pulp mill effluent on benthic assemblages in mesocosms along the Saint John River, Canada. Environ Toxicol Chem 22:29162925

de Deckere E, de Cooman W, Leloup V, Meire P, Schmitt C, von der Ohe PC (2011) Development of sediment quality guidelines for freshwater ecosystems. J Soils Sediments 11:504-517

De Lange HJ, Noordoven W, Murk AJ, Lürling M, Peeters ETHM (2006a) Behavioural responses of Gammarus pulex (Crustacea, Amphipoda) to low concentrations of pharmaceuticals. Aquat Toxicol 78:209-216

De Lange HJ, Sperber V, Peeters ETHM (2006b) Avoidance of polycyclic aromatic hydrocarbon-contaminated sediments by the freshwater invertebrates Gammarus pulex and Asellus aquaticus. Environ Toxicol Chem 25:452-457

DeGraeve GM, Cooney JD, Marsh BH, Pollock TL, Reichenbach NG (1992) Variability in the performance of the 7-d Ceriodaphnia dubia survival and reproduction test: an intra- and interlaboratory study. Environ Toxicol Chem 11:851-866

Deutsches Institut für Normung (1989) Deutsche Einheitsverfahren zur Wasser-, Abwasser- und Schlammuntersuchung; Schlamm und Sedimente (Gruppe S); Bestimmung von ausblasbaren und extrahierbaren, organisch gebundenen Halogenen. DIN 38414 $17,17 \mathrm{pp}$

Deutsches Institut für Normung (2005) Charakterisierung von Abfällen-Bestimmung des Gehalts an Kohlenwasserstoffen von C10 bis C40 mittels Gaschromatographie; Deutsche Fassung EN 14039:2004. DIN EN 14039, 24 pp

Drummond RA, Russom CL (1990) Behavioral toxicity syndromes: a promising tool for assessing toxicity mechanisms in juvenile fathead minnows. Environ Toxicol Chem 9:37-46
Emmanuel E, Keck G, Blanchard J-M, Vermande P, Perrodin Y (2004) Toxicological effects of disinfections using sodium hypochlorite on aquatic organisms and its contribution to AOX formation in hospital wastewater. Environ Int 30:891-900

EPA (1996a) EPA Method 8082: Polychlorinated biphenyls (PCBs) by gas chromatography, CD-ROM 8082, Revision 0. December 1996, 56 pp. http://www.epa.gov/osw/hazard/testmethods/sw846/ pdfs/8082a.pdf

EPA (1996b) EPA Method 8270C: Semivolatile organic compounds by gas chromatography/mass spectrometry (GC/MS), CD-ROM 8270C, Revision 3. December 1996, 72 pp. http://www.epa.gov/ osw/hazard/testmethods/sw846/pdfs/8270d.pdf

EPA (2002) EPA-821-R-02-013: Short-term methods for estimating the chronic toxicity of effluents and receiving waters to freshwater organisms. Washington, DC, USA, $335 \mathrm{pp}$

Escher BI, Bramaz N, Quayle P, Rutishauser S, Vermeirssen ELM (2008) Monitoring of the ecotoxicological hazard potential by polar organic micropollutants in sewage treatment plants and surface waters using a mode-of-action based test battery. J Environ Monit 10:622-631

Finger SE, Little EF, Henry MG, Fairchild JF, Boyle TP (1985) ASTM STP 865: Comparison of laboratory and field assessment of fluorene-part I: effects of fluorene on the survival, growth, reproduction, and behavior of aquatic organisms in laboratory tests. In: Boyle TP (ed) Validation and predictability of laboratory methods for assessing the fate and effects of contaminants in aquatic ecosystems. American Society for Testing and Materials, Philadelphia, Pennsylvania, USA, pp 120-133

Gala WR, Giesy JP (1992) Photoinduced toxicity of anthracene to the green alga, Selenastrum capricornutum. Arch Environ Contam Toxicol 23:316-323

Gellert G (2000) Relationship between summarizing chemical parameters like $\mathrm{AOX}, \mathrm{TOC}, \mathrm{TNb}$, and toxicity tests for effluents from the chemical production. Bull Environ Contam Toxicol 65:508-513

Gerbersdorf SU, Hollert H, Brinkmann M, Wieprecht S, Schüttrumpf H, Manz W (2011) Anthropogenic pollutants affect ecosystem services of freshwater sediments: the need for a "triad plus $\mathrm{x}$ " approach. J Soils Sediments 11:1099-1114

Gerhardt A (1999) Recent trends in online biomonitoring for water quality control. In: Gerhardt A (ed) Biomonitoring of polluted water. Trans Tech, Zürich, Switzerland, pp 95-118

Gerhardt A (2007) Aquatic behavioral ecotoxicology_prospects and limitations. Hum Ecol Risk Assess 13:481-491

Gerhardt A, Carlsson A, Ressemann C, Stich KP (1998) New online biomonitoring system for Gammarus pulex (L.) (Crustacea): in situ test below a copper effluent in south Sweden. Environ Sci Technol 32:150-156

Gerhardt A, de Bisthoven LJ, Penders E (2003) Quality control of drinking water from the River Rhine with the multispecies freshwater biomonitor. Aquat Ecosyst Health 6:159-166

Gerhardt A, Svensson E, Clostermann M, Fridlund B (1994) Monitoring of behavioral patterns of aquatic organisms with an impedance conversion technique. Environ Int 20:209-219

Glöer P, Meier-Brock C, Ostermann O (1992) Süsswassermollusken. Deutscher Jugendbund für Naturbeobachtung, Hamburg, Germany

Hecker M, Hollert H (2009) Effect-directed analysis (EDA) in aquatic ecotoxicology: state of the art and future challenges. Environ Sci Pollut Res 16:607-613

Hellou J (2011) Behavioural ecotoxicology, an "early warning" signal to assess environmental quality. Environ Sci Pollut Res 18:1-11

Hellou J, Cook A, Lalonde B, Walker P, Dunphy K, MacLeod S (2009) Escape and survival of Corophium volutator and Ilyanassa obsoleta exposed to freshwater and chlorothalonil. J Environ Sci Heal A 44:778-790 
Hollert H, Ernst M, Ahlf W, Dürr M, Erdinger L, Grund S, Keiter S, Kosmehl T, Seiler TB, Wölz J, Braunbeck T (2009) Strategies for assessing sediment toxicity - a review. Strategien zur Sedimentbewertung-Ein Überblick 21:160-176

International Organization for Standardization (1996) ISO 6468:1996: Water quality-determination of certain organochlorine insecticides, polychlorinated biphenyls and chlorobenzenes - gas chromatographic method after liquid-liquid extraction. $24 \mathrm{pp}$

International Organization for Standardization (2004) ISO 16703:2004: Soil quality-determination of content of hydrocarbon in the range $\mathrm{C} 10$ to $\mathrm{C} 40$ by gas chromatography. $21 \mathrm{pp}$

International Organization for Standardization (2008) ISO 20665:2008: Water quality-determination of chronic toxicity to Ceriodaphnia dubia. $21 \mathrm{pp}$

Karaman G, Pinkster S (1977) Freshwater Gammarus species from Europe, North Africa and adjacent regions of Asia (Crustacea, Amphipoda). I. Gammarus pulex group and related species. Bijdragen tot de Dierkunde 47:1-97

Kersten A, Hamm U, Schabel S, Öller HJ (2006) Analysis of paper mill effluents in reference to stricter EU requirements. Analyse von Papierfabrikationsabwässern vor dem Hintergrund verschärfter EU-Anforderungen, pp 90-99

Landis GW, Chapman MP (2011) Well past time to stop using NOELs and LOELs. Integr Environ Assess Manag 7:vi-vii

Langer-Jaesrich M, Köhler HR, Gerhardt A (2010a) Assessing toxicity of the insecticide thiacloprid on Chironomus riparius (Insecta: Diptera) using multiple end points. Arch Environ Contam Toxicol 58:963-972

Langer-Jaesrich M, Kienle C, Köhler H-R, Gerhardt A (2010b) Impairment of trophic interactions between zebrafish (Danio rerio) and midge larvae (Chironomus riparius) by chlorpyrifos. Ecotoxicology 19:1294-1301

Leversee GJ, Landrum PF, Giesy JP, Fannin T (1983) Humic acids reduce bioaccumulation of some polycyclic aromatic hydrocarbons. Can J Fish Aquat Sci 40(suppl 2):63-69

Lu PY, Metcalf RL, Plummer N, Mandel D (1977) The environmental fate of three carcinogens: benzo(a)pyrene, benzidine, and vinyl chloride evaluated in laboratory model ecosystems. Arch Environ Contam Toxicol 6:129-142

Lynch M (1978) Complex interactions between natural coexploitersDaphnia and Ceriodaphnia. Ecology 59:552-564

MacDonald DD, Ingersoll CG, Berger TA (2000) Development and evaluation of consensus-based sediment quality guidelines for freshwater ecosystems. Arch Environ Contam Toxicol 39:20-31

Mayer FL Jr, Ellersieck MR (1986) Manual of acute toxicity: interpretation and data base for 410 chemicals and 66 species of freshwater animals. US Department of the Interior, Fish and Wildlife Service, Washington DC, USA, 439 pp

Mayer P, Halling-Sorensen B, Sijm DTHM, Nyholm N (1998) Toxic cell concentrations of three polychlorinated biphenyl congeners in the green alga Selenastrum capricornutum. Environ Toxicol Chem 17:1848-1851

McCahon CP, Pascoe D (1988) Use of Gammarus pulex (L.) in safety evaluation tests: culture and selection of a sensitive life stage. Ecotoxicol Environ Saf 15:245-252

McKinney AD, Wade DC (1996) Comparative response of Ceriodaphnia dubia and juvenile Anodonta imbecillis to pulp and paper mill effluents discharged to the Tennessee River and its tributaries. Environ Toxicol Chem 15:514-517

Murray W (1992) Pulp and paper: the reduction of toxic effluents. Government of Canada, Science and Technology Division, Ottawa, Canada, 23 pp

Musko IB, Meinel W, Krause R, Barlas M (1990) The impact of Cd and different $\mathrm{pH}$ on the amphipod Gammarus fossarum Koch (Crustacea: Amphipoda). Comp Biochem Phys C 96:11-16

Nakari T, Huhtala S (2008) Comparison of toxicity of congener-153 of PCB, PBB, and PBDE to Daphnia magna. Ecotox Environ Saf 71:514-518
Niederlehner BR (1984) A comparison of techniques for estimating the hazard of chemicals in the aquatic environment. MSc thesis, Virginia Polytechnic Institute and State University, Blacksburg, VA, USA, 290 pp

Novak MA, Reilly AA, Bush B, Shane L (1990) In situ determination of PCB congener-specific 1st order absorption desorption rate constants using Chironomus-tentans larvae (Insecta, Diptera, Chironomidae). Water Res 24:321-327

O'Connor BI, Kovacs TG, Voss RH, Martel PH (1993) A study of the relationship between laboratory bioassay response and AOX content for pulp mill effluents. J Pulp Pap Sci 19:33-39

OECD (2004a) OECD Guidelines for the testing of chemicals 218: sediment-water chironomid toxicity test using spiked sediment. $21 \mathrm{pp}$

OECD (2004b) OECD Guidelines for the testing of chemicals 219: sediment-water chironomid toxicity test using spiked water. $21 \mathrm{pp}$

Ong SK, DeGraeve GM, Silva-Wilkinson RA, McCabe JW, Smith WL (1996) Toxicity and bioconcentration potential of adsorbable organic halides from bleached laundering in municipal wastewater. Environ Toxicol Chem 15:138-143

Oris JT, Winner RW, Moore MV (1991) A four-day survival and reproduction toxicity test for Ceriodaphnia dubia. Environ Toxicol Chem 10:217-224

Pascoe D, Williams KA, Green DWJ (1989) Chronic toxicity of cadmium to Chironomus riparius Meigen - effects upon larval development and adult emergence. Hydrobiologia 175:109-115

Pellinen J, Soimasuo R (1993) Toxicity of sediments polluted by the pulp and paper industry to a midge (Chironomus riparius Meigen). Sci Total Environ 134(suppl 2):1247-1256

Postma JF, Vankleunen A, Admiraal W (1995) Alterations in life-history traits of Chironomus riparius (Diptera) obtained from metalcontaminated rivers. Arch Environ Contam Toxicol 29:469-475

Rosa R, Moreira-Santos M, Lopes I, Silva L, Rebola J, Mendonça E, Picado A, Ribeiro R (2010) Comparison of a test battery for assessing the toxicity of a bleached-kraft pulp mill effluent before and after secondary treatment implementation. Environ Monit Assess 161:439-451

Sanders HO, Chandler JH (1972) Biological magnification of a polychlorinated biphenyl (Aroclor 1254) from water by aquatic invertebrates. Bull Environ Contam Toxicol 7:257-263

Sanz-Lazaro C, Marin A, Borredat M (2008) Toxicity studies of polynuclear aromatic hydrocarbons (PAHs) on European amphipods. Toxicol Mech Method 18:323-327

Schreiber U, Quayle P, Schmidt S, Escher BI, Mueller JF (2007) Methodology and evaluation of a highly sensitive algae toxicity test based on multiwell chlorophyll fluorescence imaging. Biosens Bioelectron 22:2554-2563

Schuler LJ, Landrum PF, Lydy MJ (2004) Time-dependent toxicity of fluoranthene to freshwater invertebrates and the role of biotransformation on lethal body residues. Environ Sci Technol 38:6247-6255

Schweizerischer Bundesrat (1998) Verordnung über die Sanierung von belasteten Standorten (Altlasten-Verordnung, AltlV) vom 26. August 1998 (Stand am 1. August 2011), 20 pp

Sibley PK, Legler J, Dixon DG, Barton DR (1997) Environmental health assessment of the benthic habitat adjacent to a pulp mill discharge. I. Acute and chronic toxicity of sediments to benthic macroinvertebrates. Arch Environ Contam Toxicol 32:274-284

Soeter A, Bakker F, Velthuis M, Verweij R, Hoitinga L, Marinkovic M, Kraak M, Breeuwer J (2010) The selective environment: genetic adaptation of the midge Chironomus riparius to metal pollution. Proc Neth Entomol Soc Meet 21:85-94

Sofyan A, Price DJ, Birge WJ (2007) Effects of aqueous, dietary and combined exposures of cadmium to Ceriodaphnia dubia. Sci Total Environ 385:108-116

Sofyan A, Shaw JR, Birge WJ (2006) Metal trophic transfer from algae to cladocerans and the relative importance of dietary metal exposure. Environ Toxicol Chem 25:1034-1041 
Stewart KM, Thompson RS (1995) Fluoranthene as a model toxicant in sediment studies with Chironomus riparius. J Aquat Ecosys Health 4:231-238

Studemann D, Landolt P, Sartori M, Hefti D, Tomka I (1992) Ephemeroptera Insecta Helvetica-Fauna. Schweizerische Entomologische Gesellschaft, Fribourg, 173 pp

Van Dam RA, Harford AJ, Warne MSJ (2012) Time to get off the fence: the need for definitive international guidance on statistical analysis of ecotoxicity data. Integr Environ Assess Manag 8:242-245

Van der Heever JA, Grobbelaar JU (1996) The use of Selenastrum capricomutum growth potential as a measure of toxicity of a few selected compounds. Water SA 22:183-191

Verrhiest G, Ciément B, Blake G (2001) Single and combined effects of sediment-associated PAHs on three species of freshwater macroinvertebrates. Ecotoxicology 10:363-372

Waringer J, Graf W (1997) Köcherfliegen (Trichoptera) Larven. Atlas der österreichischen Köcherfliegenlarven unter Einschluss der angrenzenden Gebiete. Facultas Verlag, pp 288
Welton JS (1979) Life-history and production of the amphipod Gammarus pulex in a Dorset chalk stream. Freshw Biol 9:263-275

Wichard W, Arens W, Eisenbeis G (1995) Atlas zur Biologie der Wasserinsekten. Gustav Fischer, Stuttgart, Germany, 338 pp

Wildhaber ML, Schmitt CJ (1998) Indices of benthic community tolerance in contaminated Great Lakes sediments: relations with sediment contaminant concentrations, sediment toxicity, and the sediment quality triad. Environ Monit Assess 49:23-49

Wildi E, Nagel R, Steinberg CEW (1994) Effects of pH on the bioconcentration of pyrene in the larval midge, Chironomus riparius. Water Res 28:2553-2559

Wolfram G, Höss S, Orendt C, Schmitt C, Adámek Z, Bandow N, Großschartner M, Kukkonen JVK, Leloup V, López Doval JC, Muñoz I, Traunspurger W, Tuikka A, Van Liefferinge C, von der Ohe PC, de Deckere E (2012) Assessing the impact of chemical pollution on benthic invertebrates from three different European rivers using a weight-of-evidence approach. Sci Total Environ 438:498-509 